\title{
Gender, Personal Traits, and Entrepreneurial Intentions
}

\author{
José C. Sánchez ${ }^{1} \&$ Brizeida R. Hernández-Sánchez ${ }^{1}$ \\ ${ }^{1}$ Director, Chair of Entrepreneurship, University of Salamanca, Avenida de la Merced, 109, 37005 Salamanca, \\ Spain. \\ Correspondence: José C. Sánchez, Director, Chair of Entrepreneurship, University of Salamanca, Avenida de la \\ Merced, 109, 37005 Salamanca, Spain. E-mail: jsanchez@usal.es
}

Received: February 2, 2014

Accepted: February 19, 2014

Online Published: February 26, 2014

doi:10.5430/bmr.v3n1p31

URL: http://dx.doi.org/10.5430/bmr.v3n1p31

\begin{abstract}
Gender differences in entrepreneurial intentions and agentic traits frequently linked to entrepreneurship (locus of control, entrepreneurial self-efficacy, risk-taking propensity, and proactiveness) were examined using a sample of 535 women and 283 men, all of them university students. Self-report data were collected through a questionnaire consisting of several scales. MANOVA results showed gender differences in entrepreneurial intention and entrepreneurial self-efficacy, men feeling more efficient to create a new venture and being more prone to do so than women. Nevertheless, major area and age explained differences in the variables studied better than gender. All this evidence supports the idea that the lower entrepreneurial activity observed in women refers not only to the verifiable creation of a new business, but that it extends to the first phase relating to career choice and the formation of intentions in this respect. This raises the need to approach the problem of scarce entrepreneurial initiatives in women from the very early stages of career choice, when the person is still weighing the different job alternatives and making decisions about them.
\end{abstract}

Keywords: Entrepreneurship, Career choice, Gender-role stereotypes, Agentic traits

\section{Introduction}

Although the traditional labor division between genders has actually dissipated in many western societies, and women are increasingly occupying job positions typically dominated by men, a gap still prevails in the working life of men and women. Gender differences are especially evident in entrepreneurial careers (Sanchez \& Licciardello, 2012). In spite of the fact that in recent years there has been a significant increase in the number of new ventures created by women, the proportion of these in comparison to the total is still small. In this sense, different investigations have found systematically a greater tendency towards entrepreneurship in men rather than in women (Zhao, Seibert, \& Hills, 2005).

Authors from different countries agree in explaining the scarce involvement of women in business initiatives based on the obstacles that they typically face in comparison to men (Jome, Donahue, \& Siegel, 2006), the existence of differential motives between individuals of both sexes to create a new venture (Justo, Cruz, De Castro, \& Coduras, 2005), or certain psychological characteristics that would occur in different levels in men and women, thus creating a differential disposition towards self-employment.

However, the proposed explanations to account for the scarce entrepreneurial behavior observed in women come fundamentally from studies that only focused on samples of established and experienced entrepreneurs. Nevertheless, the new venture creation process occurs in the long term and involves multiple successive stages, which go from the formation of an entrepreneurial intention as a result of a meditated decision of career choice, to the development of real entrepreneurial behavior with the implementation of a new business idea. From this point of view, the analysis of gender differences in initial entrepreneurial career choices could suggest new insights for understanding the low rates of female entrepreneurs in different regions around the world.

Following this argument, our aim is to answer two fundamental questions: Have men a higher intention to start a business than women?, and, Do such gender differences extend to other entrepreneurial traits, such as locus of control, entrepreneurial self-efficacy, risk-taking propensity, and proactiveness? Drawing on literature about gender differences in career-related processes (Abele, 2000) and person-organization fit (Ehrhart, 2006), we propose that gender roles and stereotypes cause differences between genders in certain psychological traits strongly associated with entrepreneurial intentions and choices. To analyze this premise we conducted a self-report-based study from a 
sample of university students involved in career choice processes, in order to analyze gender differences in entrepreneurial intentions and traits.

\subsection{Gender Differences in Entrepreneurial Intentions and Traits}

The intention to start a new business represents the first step in the entrepreneurial sequence. Intentions capture the motivational factors affecting a specific behavior, and show the individual's predisposition for undertaking such behavior. That is why, in psychological literature (Ajzen, 1991), intentions appear as a good predictor of planned behavior. The creation of a new company demands time and implies considerable planning. It is difficult to imagine the creation of a business merely as a response to a stimulus and not as a planned decision involving some degree of cognitive processing. Thus, entrepreneurial behavior is precisely the type of planned behavior for which intention models are ideally suitable (Krueger, Reilly, \& Carsrud, 2000).

Several authors have argued that the agentic traits of internal locus of control, entrepreneurial self-efficacy, risk-taking propensity, and proactiveness not only differentiate between entrepreneurs and non-entrepreneurs, but they also influence the intention to start a business. In the first place, internal locus of control implies a high perception of control and feasibility in relation to specific behavior, which is a powerful predictor of intention (Shapero \& Shokol, 1982). That is why internal locus of control has frequently been linked to the development of entrepreneurial intentions (Krueger, 1993).

Also, self-efficacy perceptions seem to be very helpful in understanding planned and intentional behavior, given their influence in the formation of intentions by situational perceptions of feasibility (Krueger, 2000). The level of self-efficacy predicts career choice and occupational interests, including the entrepreneurial option. People avoid careers and environments which they believe exceed their capacities, and undertake careers for which they consider themselves capable (Krueger \& Dickson, 1994). In this sense, one might argue that individuals should be inclined to develop entrepreneurial careers whenever they judge themselves to have the skills needed to cope with the requirements of such an environment (Krueger \& Brazeal, 1994). In fact, in recent years, some research studies have successfully demonstrated the predictive power of entrepreneurial self-efficacy beliefs in relation to the formation of entrepreneurial intentions, both through their direct influence over them and through their association with other variables (Sánchez, Lanero, \& Yurrebaso, 2005; Segal, Borgia, \& Schoenfeld, 2005).

Third, since entrepreneurial initiative involves considerable risk and uncertainty, those individuals with a greater dispositional tendency to tolerate and get involved in risky situations will consider entrepreneurship as a very attractive alternative in their career decision making, and so they will be more likely to develop the intention to start a new venture. Thus, we can predict that the individuals most prone to risk will perceive entrepreneurial behavior as very desirable, which is a relevant condition for entrepreneurial intentions development. It has also been found that risk propensity is positively associated with self-employment intentions through its influence on certain predictors of these intentions, such as entrepreneurial self-efficacy (Zhao et al., 2005) and a positive attitude towards entrepreneurial behavior (Lüthje \& Franke, 2003).

Finally, considering that the prototypical traits of proactive personalities (such as orientation to action and change, perseverance, and identification of and acting on opportunities) are critical for the entrepreneurial initiatives development, proactiveness seems to have great implications for self-employment status choice and entrepreneurial intentions formation. In fact, Crant (1996) found that entrepreneurial intentions were positively associated with having a proactive personality. This type of personality orientation has also been mentioned an important precursor to entrepreneurial intentions and potential (Sánchez et al. 2005).

As we have previously noted, the evidence suggests that men commonly show agentic traits, whereas women manifest communal traits to a great extent. Since the four psychological dimensions examined are examples of agentic traits, we predict that they will be more characteristic of men than of women, as a result of a process of accommodation to distinctive gender roles and stereotypes.

\subsection{Major Area and Age}

The analysis of the relationship between gender and entrepreneurial intentions and traits requires taking into account other individual dimensions that could affect such variables. For instance, it has been observed that educational background plays an important role in the development of entrepreneurial intentions (Wasylow, Mellot, \& Martin, 2006). Furthermore, men students are the majority in Technical and Experimental Sciences, which offer high possibilities for self-employment; whereas women choose predominantly Social and Health majors, which are more oriented to wage employment. From this view, major area represents a critical control variable in this study, since it could be confounded with gender in explaining entrepreneurial intentions and traits. 
Age is another variable highly related to the dimensions of this study. In several countries, early-stage entrepreneurial activity is most prevalent in the 25-34 years-old age group (Allen et al., 2006). For this reason, the older students could have a higher entrepreneurial intention than their younger counterparts. On the other hand, studies have found age differences in personality and other psychological dimensions, individuals aged between 20 and 30 being a group of special change because of the natural processes of psychological maturity (De Miguel, 2005). Hence, age could be confounded with gender and it is necessary to control for its effects on entrepreneurial intentions and traits.

According to the dual-process model (Abele, 2000) and the person-organization fit perspective (Cable \& Judge, 1996), we propose that gender affects entrepreneurial intentions and traits, and that the differences between the sexes in entrepreneurial career choice are associated with the fit level of men's and women's personal characteristics with the entrepreneurial requirements. Specifically, we propose two hypotheses:

Hypothesis 1. After controlling for major area and age, men will have a higher level of entrepreneurial intention than women.

Hypothesis 2. After controlling for major area and age, men will have higher levels than women on:

(2a) locus of control; (2b) entrepreneurial self-efficacy; (2c) risk-taking propensity; and (2d) proactiveness.

\section{Method}

\subsection{Sample}

Data was collected from 818 participants (34.6\% males and 65.4\% females), aged between 18 and 26 years old, and with a mean age of $21.67(S D=2.18) .48 \%$ of the participants were aged between 18 and 21 , and the remaining $52 \%$ were aged between 22 and 26 years old. The sample was comprised of university students from different knowledge areas, with a predominance of Social Sciences (31.4\%), Business and Economic Sciences (25.3\%), Technical Sciences (15.3\%), Humanities (9.2\%), Educational Sciences (9.1\%), Experimental Sciences (4.6\%), Health Sciences (3.2\%), and Legal Sciences (1.9\%). Using a sample of students allows us to work with people actually involved in processes of occupational career choice (Krueger et al., 2000) and, in accordance with our research aims, makes it possible to study gender differences in the antecedents of entrepreneurial intentions.

The sample of women comprised 535 participants with a mean age of $21.58(S D=2.06) .50 .8 \%$ of participants were aged between 18 and 21, and the remaining $49.2 \%$ were aged between 22 and 26 years old. The distribution of the sample of women by major areas was: $42.6 \%$ Social Sciences, $22.2 \%$ Business and Economic Sciences, 9.1\% Technical Sciences, 8.7\% Educational Sciences, 8.2\% Humanities, 3.8\% Health Sciences, 3\% Experimental Sciences, and $2.3 \%$ Legal Sciences.

The sample of men was comprised of 283 participants with a mean age of $21.85(S D=2.38) .42 .8 \%$ of the men were aged between 18 and 21, and 57.2\% were between 22 and 26 years old. The distribution of the sample of men by major areas was: 31\% Business and Economic Sciences, 27.1\% Technical Sciences, 11.2\% Humanities, 10.1\% Social Sciences, 9.7\% Educational Sciences, 7.6\% Experimental Sciences, 2.2\% Health Sciences, and 1.1\% Legal Sciences.

\subsection{Instruments}

Data was collected by administering questionnaires to the total sample, by experts in programmed classes. All the subjects voluntarily answered the questionnaire, which consisted of different sections and scales which will now be described. The time period during which the survey took place was from October to December.. Reliabilities of scales assessed by Cronbach's alpha are shown in Table 1.

Entrepreneurial intention. In line with Krueger et al. (2000), we used a single item measure of the intention to start a business. We evaluated this by asking the participants to indicate their intention to start their own business in the next five years on a Likert type scale from 0 (low intention) to 10 (high intention). The items were averaged to form an overall measure.

Locus of control. The study posed 20 items adapted from previous research (Hoffman, Novak, \& Schlosser, 2003), referring to individuals' expectancies for internal versus external control of reinforcement. Examples of items are: "In general, whatever happens in my life will be closely related to what I do", or "Whatever happens in my life has to do with luck" (inverted item). Participants answered on a Likert type scale from 0 (totally in disagreement) to 5 (totally in agreement). The items were averaged to form an overall measure. 
Entrepreneurial self-efficacy. We used the Entrepreneurial Self-efficacy Scale by De Noble, Jung, \& Ehrlich (1999), which measures the belief of a person in his/her own abilities to carry out the tasks required for creating a business. The scale is composed of 23 items and participants express whether they feel able or not to do what is indicated in each item. Scores range from 1 to 10, ranging from "completely incapable" to "perfectly able". Examples of items are: "I can see new market opportunities for new products and services", or "I can develop and maintain favorable relationships with potential investors". An overall score is obtained by averaging the 23 items.

Risk-taking propensity. A reduced version of the Risk Orientation Questionnaire (ROQ) was used (Rohrmann, 1997), which evaluates the general tendency of the person to assume risks based on a series of items about the propensity to and avoidance of risky situations. In total, participants answered eight items referring to risk-facing and attitudes towards risk decisions. Examples of items are: "Even when I know that my chances are limited I try my luck", or "I am quite cautious when I make plans and when I act on them" (inverted item). Answers were categorized in a Likert type scale ranging from 0 (totally in disagreement) to 5 (totally in agreement). The eight items were averaged to form an overall measure.

Proactiveness. We used a reduced version of the Proactive Personality Scale (Seibert, Kraimer, and Crant, 2001). The adapted 10 items assessed the participants' agreement or disagreement with a series of statements referring to typical actions of proactive people such as opportunity identification, using a 5-point Likert scale from 0 (totally in disagreement) to 5 (totally in agreement). Examples of items are: "I am constantly on the lookout for new ways to improve my life", or "I am great at turning problems into opportunities". An overall score was obtained by averaging the 10 items.

Control variables. To control for major area, participants were asked to report their college major, and answers were coded. Also, participants were asked to report their age, and answers were coded in the following manner to create a categorical variable: 1 = younger group (18-21 years old); $2=$ older group $(22-26$ years old $)$.

\section{Results}

First of all, we ran two chi-square analyses to determine whether major area and age group were confounded with gender. To examine gender differences in major area we carried out a 2 (gender) $\times 8$ (major area) chi-square analysis. This analysis was significant, $\chi^{2}(7, N=818)=117.72, p<.001$. Men were more likely than women to be studying Business and Economic Sciences (31\% and 22.2\%, respectively), Technical Sciences (27.1\% and 9.1\%), Humanities (11.2\% and 8.2\%), Educational Sciences (9.7\% and 8.7\%), and Experimental Sciences (7.6\% and 3\%). In contrast, women were more likely than men to be coursing Social Sciences ( $42.6 \%$ and $10.1 \%$, respectively), Health Sciences (3.8\% and 2.2\%), and Legal sciences $(2.3 \%$ and $1.1 \%$ ). We ran a second 2 (gender) $\times 2$ (age group) chi-square analysis to examine gender differences in age group. This analysis was also significant, $\chi^{2}(1, N=818)=4.53, p<.05$ according to Yates' correction for continuity. Men were more likely than women to be aged between 22 and 26 years old $(57.2 \%$ and $49.2 \%$, respectively), whereas women were more likely than men to be aged between 18 and 21 (50.8\% and $42.8 \%$, respectively). These results suggest that major area and age group are confounded with gender in this study and it is necessary to include them as control variables in the analyses. Table 1 presents the means, standard deviations, alpha coefficients, and intercorrelations of the study variables. Regardless of gender, mean scores in entrepreneurial intentions and traits were relatively low in the total sample.

Table 1. Means, Standard Deviations, Reliabilities, and Correlations of Study Variables

\begin{tabular}{lccccccc}
\hline \multicolumn{1}{c}{ Variable } & 1 & 2 & 3 & 4 & 5 & 6 & 7 \\
\hline 1. Entrepreneurial intention & -- & & & & & & \\
2. Locus of control & $.12^{\mathrm{b}}$ & $(.76)$ & & & & & \\
3. Entrepreneurial self-efficacy & $.19^{\mathrm{b}}$ & $.30^{\mathrm{b}}$ & $(.88)$ & & & & \\
4. Risk-taking propensity & $.13^{\mathrm{b}}$ & $.29^{\mathrm{b}}$ & $.31^{\mathrm{b}}$ & $(.71)$ & & & \\
5. Proactiveness & $.22^{\mathrm{b}}$ & $.33^{\mathrm{b}}$ & $.50^{\mathrm{b}}$ & $.45^{\mathrm{b}}$ & $(.78)$ & & \\
6. Gender & $-.09^{\mathrm{a}}$ & -.01 & -.04 & -.02 & -.06 & -- & \\
7. Major area & .04 & .04 & $-.08^{\mathrm{a}}$ & .06 & .03 & -.03 & -- \\
8. Age group & -.01 & -.01 & $.07^{\mathrm{a}}$ & .02 & .01 & $-.14^{\mathrm{b}}$ & $-.14^{\mathrm{b}}$ \\
Mean & 2.61 & 3.30 & 4.99 & 2.73 & 3.31 & -- & -- \\
Standard Deviation & 2.37 & .59 & 1.64 & .61 & .58 & -- & --
\end{tabular}

Cronbach's alphas are in parentheses. ${ }^{\mathrm{a}} p<.05 ;{ }^{\mathrm{b}} p<.01$. Scores of entrepreneurial intention, locus of control, risk-taking propensity, and proactiveness range from 0 to 5 ; scores of entrepreneurial self-efficacy range from 0 to 10 
In accordance with hypotheses 1 and 2, we carried out a three-way between-subjects factorial MANOVA to assess the existence of significant differences in entrepreneurial intentions and traits between genders, after controlling for major area and age group. Gender, major area, age group, and the interactions between them served as independent variables, and the dependent variables were entrepreneurial intention, locus of control, entrepreneurial self-efficacy, risk-taking propensity, and proactiveness. Table 2 contains the means and standard deviations of the individual variables by gender, major area, and age group.

Table 2. Means of individual variables by gender, major area, and age group

\begin{tabular}{|c|c|c|c|c|c|c|c|c|c|c|}
\hline \multirow{2}{*}{$\begin{array}{l}\text { Samples (n) } \\
\text { Gender }\end{array}$} & \multicolumn{10}{|c|}{ Dimensions } \\
\hline & \multicolumn{2}{|c|}{$\begin{array}{l}\text { Entrepreneurial } \\
\text { intention }^{\mathrm{ab}}\end{array}$} & \multicolumn{2}{|c|}{$\begin{array}{c}\text { Locus of } \\
\text { control }\end{array}$} & \multicolumn{2}{|c|}{$\begin{array}{l}\text { Entrepreneurial } \\
\text { self-efficacy }^{\mathrm{a}}\end{array}$} & \multicolumn{2}{|c|}{$\begin{array}{l}\text { Risk-taking } \\
\text { propensity }\end{array}$} & \multicolumn{2}{|c|}{ Proactiveness } \\
\hline Men (249) & 3.09 & $(2.56)$ & 3.31 & $(.60)$ & 5.15 & $(1.61)$ & 2.76 & $(.65)$ & 3.39 & $(.58)$ \\
\hline Women (483) & 2.62 & $(2.36)$ & 3.30 & $(.60)$ & 4.95 & $(1.62)$ & 2.73 & $(.59)$ & 3.30 & $(.58)$ \\
\hline $\begin{array}{l}\text { Business and Sciences } \\
\text { (189) }\end{array}$ & 2.87 & $(2.39)$ & 3.25 & $(.55)$ & 5.20 & $(1.54)$ & 2.73 & $(.65)$ & 3.38 & $(.57)$ \\
\hline Humanities (61) & 2.08 & $(2.68)$ & 3.15 & $(.67)$ & 4.96 & $(1.85)$ & 2.73 & (.64) & 3.29 & $(.73)$ \\
\hline Social Sciences (242) & 2.78 & $(2.33)$ & 3.40 & $(.61)$ & 5.04 & $(1.59)$ & 2.73 & $(.57)$ & 3.25 & $(.56)$ \\
\hline Experimental Sciences (31) & 1.45 & $(2.19)$ & 3.35 & $(.47)$ & 4.74 & $(1.71)$ & 2.70 & $(.62)$ & 3.24 & $(.73)$ \\
\hline Technical Sciences (106) & 3.02 & $(2.59)$ & 3.22 & $(.67)$ & 5.17 & $(1.76)$ & 2.77 & $(.66)$ & 3.48 & $(.53)$ \\
\hline Legal Sciences (14) & 4.00 & $(3.37)$ & 3.53 & $(.62)$ & 4.22 & $(1.49)$ & 2.54 & (.64) & 3.26 & $(.73)$ \\
\hline Health Sciences (22) & 3.27 & $(1.93)$ & 3.23 & $(.47)$ & 4.28 & $(1.15)$ & 2.54 & $(.43)$ & 3.23 & $(.53)$ \\
\hline Educational Sciences (67) & 2.47 & $(2.31)$ & 3.31 & $(.51)$ & 4.78 & $(1.52)$ & 2.89 & $(.62)$ & 3.33 & $(.53)$ \\
\hline \multicolumn{11}{|l|}{ Age group } \\
\hline $18-21(356)$ & 2.81 & $(2.35)$ & 3.30 & $(.55)$ & 4.93 & $(1.53)$ & 2.73 & $(.60)$ & 3.31 & $(.56)$ \\
\hline $22-26(376)$ & 2.75 & $(2.53)$ & 3.31 & (.64) & 5.11 & (1.69) & 2.75 & $(.62)$ & 3.34 & $(.60)$ \\
\hline
\end{tabular}

Standard deviations are shown in parentheses. ${ }^{a}$ Denotes differences between men and women. ${ }^{b}$ Denotes differences between Experimental Sciences and Business and Economic Sciences, Technical Sciences, and Legal Sciences

In the first place, the multivariate effect of gender was significant, indicating significant differences in entrepreneurial intentions and traits between men and women, $F(5,700)=2.81, p<.05, \chi^{2}=.98$, by Wilk's lambda criterion. Analyses of variance (ANOVA) on each dependent variable were conducted as follow-up test to the MANOVA. The univariate main effect of gender was significant for entrepreneurial intention, $F(27,704)=11.44, p$ $<.001$, with men scoring higher than women (Men, $M=3.09, D T=2.56$; Women, $M=2.62, D T=2.36$ ), as is shown in Table 2. This result confirms our hypothesis 1 . There was also a univariate effect of gender on entrepreneurial self-efficacy, $F(27,704)=3.90, p<.05$. As is shown in Table 2, again men scored higher than women (Men, $M=$ $5.15, D T=1.61$; Women, $M=4.95, D T=1.62$ ). These results partially support our hypothesis 2 in the sense that, according to what was expected, men showed greater levels of entrepreneurial self-efficacy than women did, but otherwise, there were no gender differences in locus of control, risk-taking propensity, and proactiveness.

Secondly, the multivariate effect of major area was also significant in the MANOVA, indicating that participants in different major areas differed based on the set of entrepreneurial variables analyzed, $F(35,2947)=1.63, p<.05, \chi^{2}$ $=.92$, by Wilk's lambda criterion. ANOVAs on each dependent variable were conducted as follow-up tests to the MANOVA. The univariate effect of major area was significant only for entrepreneurial intention, $F(27,704)=3.36$, $p<.01$. Tukey post hoc analyses showed that students of Experimental Sciences scored significantly lower in the entrepreneurial intention item than students of Business and Economic Sciences, Technical Sciences, and Legal Sciences (Experimental Sciences, $M=1.45, S D=2.19$; Business and Economic Sciences, $M=2.87, S D=2.39$; Technical Sciences, $M=3.02, S D=2.59$; and Legal Sciences, $M=4.00, S D=3.37$ ).

Finally, the multivariate effect of major area $\times$ age group interaction was significant in the MANOVA, indicating significant differences in entrepreneurial intentions and traits between participants of different major areas in each 
age group, $F(30,2802)=1.97, p<.001, \chi^{2}=.92$, by Wilk's lambda criterion. ANOVAs on each dependent variable were conducted as follow-up tests to the MANOVA. The univariate effect of the interaction was significant for locus of control, $F(27,704)=3.60, p<.01$, entrepreneurial self-efficacy, $F(27,704)=2.27, p<.05$, risk-taking propensity, $F(27,704)=2.78, p<.05$, and proactiveness, $F(27,704)=2.45, p<.05$. Tukey post hoc analyses showed a differential effect of major area on the four psychological variables between older and younger groups (18-21 vs. 22-26). In the younger group students of Business and Economic Sciences scored significantly higher in entrepreneurial self-efficacy than students of Social Sciences. Also, there were significant differences in risk-taking propensity between students of Educational Sciences and Social Sciences. And finally, students of Social Sciences showed lower levels of proactiveness than their counterparts from Technical Sciences and Business and Economic Sciences. In the group of older students, Tukey post hoc analyses showed that students of Social Sciences showed higher levels of internal locus of control than their counterparts from Business and Economic Sciences, Technical Sciences, and Humanities. These results are shown in Table 3.

Table 3 . Means of individual variables by major area $\times$ age group

\begin{tabular}{|c|c|c|c|c|c|c|c|c|c|c|}
\hline \multirow{2}{*}{$\begin{array}{l}\text { Samples } \\
\text { Younger group (18-21) }\end{array}$} & \multicolumn{10}{|c|}{ Dimensions } \\
\hline & \multicolumn{2}{|c|}{$\begin{array}{c}\text { Entrepreneurial } \\
\text { intention }\end{array}$} & \multicolumn{2}{|c|}{$\begin{array}{l}\text { Locus of } \\
\text { control }^{\text {a }}\end{array}$} & \multicolumn{2}{|c|}{$\begin{array}{l}\text { Entrepreneurial } \\
\text { self-efficacy }^{b}\end{array}$} & \multicolumn{2}{|c|}{$\begin{array}{l}\text { Risk-taking } \\
\text { propensity }^{c}\end{array}$} & \multicolumn{2}{|c|}{ Proactiveness } \\
\hline Business and sciences & 2.82 & $(2.47)$ & 3.31 & $(.51)$ & 5.25 & $(1.50)$ & 2.77 & $(.61)$ & 3.41 & $(.51)$ \\
\hline Social Sciences & 2.77 & $(2.36)$ & 3.29 & $(.58)$ & 4.84 & $(1.53)$ & 2.63 & $(.57)$ & 3.19 & $(.59)$ \\
\hline Experimental Sciences & 1.22 & (1.64) & 3.13 & $(.56)$ & 5.64 & $(1.76)$ & 2.47 & $(.73)$ & 3.40 & $(.72)$ \\
\hline Technical Sciences & 3.11 & $(2.54)$ & 3.40 & $(.60)$ & 5.14 & $(1.58)$ & 2.88 & $(.59)$ & 3.58 & $(.52)$ \\
\hline Legal Sciences & 2.83 & $(2.14)$ & 3.30 & $(.60)$ & 3.89 & $(1.37)$ & 2.31 & $(.74)$ & 3.07 & $(.83)$ \\
\hline Health Sciences & 3.27 & (1.93) & 3.23 & $(.47)$ & 4.28 & $(1.15)$ & 2.57 & $(.43)$ & 3.23 & $(.53)$ \\
\hline Educational Sciences & 2.73 & $(2.17)$ & 3.31 & $(.54)$ & 4.59 & $(1.54)$ & 2.95 & $(.62)$ & 3.28 & $(.52)$ \\
\hline \multicolumn{11}{|l|}{ Older group (22-26) } \\
\hline Business and Sciences & 2.99 & $(2.34)$ & 3.20 & $(.61)$ & 5.17 & $(1.61)$ & 2.69 & $(.70)$ & 3.35 & $(.67)$ \\
\hline Humanities & 1.98 & $(2.59)$ & 3.13 & $(.66)$ & 4.91 & $(1.82)$ & 2.72 & (.63) & 3.26 & $(.71)$ \\
\hline Social Sciences & 2.78 & $(2.31)$ & 3.51 & $(.62)$ & 5.25 & $(1.62)$ & 2.84 & $(.55)$ & 3.32 & $(.53)$ \\
\hline Experimental Sciences & 1.55 & $(2.40)$ & 3.44 & $(.41)$ & 4.37 & $(1.59)$ & 2.79 & $(.57)$ & 3.18 & $(.74)$ \\
\hline Technical Sciences & 2.97 & $(2.64)$ & 3.14 & $(.70)$ & 5.19 & $(1.86)$ & 2.72 & (.69) & 3.43 & $(.54)$ \\
\hline Legal Sciences & 4.88 & $(3.98)$ & 3.71 & $(.61)$ & 4.47 & $(1.62)$ & 2.72 & $(.53)$ & 3.40 & $(.66)$ \\
\hline \multicolumn{11}{|c|}{$\begin{array}{l}\text { Standard deviations are shown in parentheses. }{ }^{a} \text { Denotes differences between Social Sciences and Business and } \\
\text { Economic Sciences, Technical Sciences, and Humanities in the older group }(22-26) .{ }^{b} \text { Denotes differences between } \\
\text { Business and Economic Sciences and Social Sciences in the younger group }(18-21) .{ }^{\mathrm{c}} \text { Denotes differences between } \\
\text { Educational Sciences and Social Sciences in the younger group (18-21). }{ }^{\mathrm{d}} \text { Denotes differences between Social } \\
\text { Sciences and Business and Economic Sciences and Technical Sciences in the younger group (18-21) }\end{array}$} \\
\hline
\end{tabular}

\section{Discussion}

The principal aim of this study was to account for the scarce involvement of women in entrepreneurial initiatives from a perspective of career choice. Our argument was that by explaining why men develop entrepreneurial intentions and choose entrepreneurial careers to a greater extent than women, we could offer new insights to understand the low rates of female entrepreneurship and suggest ways to foster new venture creation in women. To this end, we expected that men actually involved in career decisions would have a higher entrepreneurial intention than their female counterparts, and that such gender differences would also extend to other entrepreneurial traits, specifically, locus of control, entrepreneurial self-efficacy, risk-taking propensity, and proactiveness.

As expected, men reported a higher intention to start a business than women did. Such differences are consistent with the results of previous studies made in different countries, which have suggested a greater initiative towards self-employment in men compared to women (Wilson, Marlino, \& Kickul, 2004; Zhao et al., 2005). All this evidence 
supports the idea that the lower entrepreneurial activity observed in women refers not only to the verifiable creation of a new business, but that it extends to the first phase relating to career choice and the formation of intentions in this respect. This raises the need to approach the problem of scarce entrepreneurial initiatives in women from the very early stages of career choice, when the person is still weighing the different job alternatives and making decisions about them.

In the second place, our results showed parallel gender differences in entrepreneurial self-efficacy. This finding is congruent with previous studies (Costa, Terracciano, \& McCrae, 2001; De Miguel, 2005) supporting the idea that women show predominantly communal/expressive traits, whereas men are higher in agentic/instrumental traits. Furthermore, this result suggests that gender stereotypes are widely established in culture, in the sense that the socialization process fosters the development of certain agentic traits, such as entrepreneurial self-efficacy, to a greater extent in men than in women.

In sum, these findings are in line with the prediction of the dual-impact model (Abele, 2000), referring to the effect of gender roles and stereotypes on the development of certain psychological characteristics involved in career choice. In our case, we found that gender affects the intention to start a business and the agentic trait of entrepreneurial self-efficacy, men feeling more efficient to create a venture and being more prone to do so than women. These results can also be explained from a person-organization fit perspective. That is to say, we can explain the development of entrepreneurial intentions as result of an accommodation between the personal characteristics of the individual and the requirements of new venture creation. Thus, people showing certain entrepreneurial traits such as entrepreneurial self-efficacy will be the most able to choose entrepreneurial careers. Since our results suggest that men are higher in this trait than women, we can explain the scarce involvement of the latter in entrepreneurial initiatives from a poor fit between their personal traits and the qualities required to create a new business.

Hence, our findings suggest a possible way of promoting self-employment in women, through entrepreneurship training programs addressed to future working women. These programs should incorporate components and activities for improving agentic characteristics such as entrepreneurial self-efficacy in women, in order to fight gender stereotypes and allow women to overcome the possible existing differences with respect to men. This, in turn, would allow them to place themselves on the same level of personal and psychological predisposition towards the creation of a new enterprise. Following Bandura's (1986) recommendations for raising self-efficacy, one might propose some basic activities on this matter including opportunities for executive mastery, modeling, verbal persuasion, and the positive interpretation of emotional and physical states. In fact, some studies suggest that mentoring is a useful initiative when starting up a new business, being psychological support as needed as formal support (Walters, McCabe, Kiellerup, \& Kiellerup, 2002).

Contrary to what was expected, our results have failed to demonstrate the existence of gender differences in other agentic entrepreneurial traits, specifically locus of control, risk-taking propensity, and proactiveness. This result can be linked to other previous failures in the identification of explanatory personal indicators of gender differences in entrepreneurship. For example, Cromie (1987) did not find remarkable differences between men and women in dimensions strongly related to the entrepreneurial process, such as need for achievement, locus of control, primacy of businesses, trust, independence, and planning. Therefore, the present study joins the previous literature that offers only partial support for the suggestion that gender differences in certain psychological dimensions can be at the bottom of additional gender differences in entrepreneurial intentions. In fact, in our sample major area and age explained entrepreneurial intentions and traits much better than gender.

All this evidence points to the need to investigate more in depth and with greater control the specific role carried out by people's personal characteristics and their relation to gender in our understanding of the complex entrepreneurial phenomenon. Additionally, some authors pose the need to test other alternative hypotheses that consider the influence of certain contextual variables (fundamentally, socio-demographic, motivating, and hindering aspects of the context) and their combination with personal variables, this line of investigation being quite promising in explaining gender differences in entrepreneurship (McCelland, Swail, Bell, \& Ibbotson, 2005). In this sense, it is expected that the application of this line of study to the scope of the formation of intentions towards self-employment could be more fruitful than the isolated analysis of certain personality dimensions (Sánchez, 2011, 2013).

On the other hand, while considering the possibilities of the generalization of the results, a few of the limitations of this study are worth mentioning. Perhaps the main concern is related to the use of a sample of students. This type of sample is very useful because, as was argued by some authors (Krueger et al., 2000), samples composed of students are the most appropriate for studying entrepreneurial intentions. Nevertheless, great caution should be exercised when generalizing the present results to other groups of entrepreneurs or non-students (Robinson, Stimpson, Huefner, 
\& Hunt, 1991) because of the homogeneity of certain important dimensions such as age or educational level, and the scarce degree of students' initiation in the entrepreneurial process. Although they are people actually beginning to face career decisions, students are certainly not the same as entrepreneurs, and we cannot be certain if their intentions are clear and durable and that the observed gender differences can be extended to other groups of experienced entrepreneurs. Moreover, as has been seen in this study, in a sample of university students the effects of gender are easily confounded with those of major area and age, whereas using a sample of potential non-student entrepreneurs offers the possibility of avoiding the effects of such confounding variables and generalizing the results to a great extent (Castiglione, Licciardello, Sánchez, Rampullo, \& Campione, 2013)

Secondly, we based our hypothesis on the assumption that gender roles and stereotypes lead to distinctive psychological traits in men and women, but we did not include in our study measures of gender roles or stereotypes. Future research should fill this gap and prove empirically this premise and its implications in career choice. Another problem is the use of a single item to measure the intention to start a business. Although research about intentions has often used single-item measures, multiple items would reduce measurement error and increase the reliability and validity of the measure, and thus of the research (Krueger et al., 2000). Furthermore, the present findings are based on self-reports by participants and, as such, they are subject to the potential errors and biases associated with such data. Finally, the sample was also drawn only from Spain, and thus caution should be taken when generalizing the results to other countries. Clearly, more research would be helpful in order to expand our sample.

Based on these limitations, future research is needed to analyze gender differences in entrepreneurial intentions and their antecedents using more appropriate methodologies, including more reliable entrepreneurial samples and experimental designs based on simulations and laboratory experiments. On the other hand, there is a general need for longitudinal studies in entrepreneurship, in order to examine the relationship between entrepreneurial intentions and behavior over time and the evolution of gender differences throughout the whole entrepreneurial sequence. Finally, cross-cultural studies will be helpful in order to replicate our findings in other countries and suggest the role of culture and its relationship with individual traits in explaining gender differences in entrepreneurial intentions and behaviors.

\section{References}

Abele, A. E. (2000). A dual-impact model of gender and career-related processes. In T. Eckes \& H. M. Trautner (Eds.), The developmental social psychology of gender (pp. 361-388). Mahwah, NJ: Lawrence Erlbaum associates.

Ajzen, I. (1991). The theory of planned behavior. Organizational Behavior \& Human Decision Processes, 50, 179-211. http://dx.doi.org/10.1016/0749-5978(91)90020-T

Allen, I. E., Langowitz, N., \& Minniti, M. (2006). Global Entrepreneurship Monitor. 2006 report on women and entrepreneurship. Babson Park, MA and London, UK: Babson College and London Business School.

Bandura, A. (1986). The social foundations of thought and action. Englewood Cliffs, NJ: Prentice Hall

Brindley, C. (2005). Barriers to women achieving their entrepreneurial potential. Women and risk. International Journal of Entrepreneurial Behaviour \& Research, 11(2), 144-161. http://dx.doi.org/10.1108/13552550510590554

Bruni, A., Gherardi, S., \& Poggio, B. (2004). Entrepreneur-mentality, gender and the study of women entrepreneurs. Journal of Organizational Change Management, $17(3), \quad$ 256-268. http://dx.doi.org/10.1108/09534810410538315

Cable, D. M., \& Judge, T. A. (1996). Person-organization fit, job choice decisions, and organizational entry. Organizational behavior and Human Decision Processes, 67(3), 294-311. http://dx.doi.org/10.1006/obhd.1996.0081

Castiglione, C., Licciardello, O. Sánchez, J.C., Rampullo, A., \& Campione, C. (2013). Liquid modernity and entrepreneurship orientation in university students. Procedia - Social and Behavioral Sciences 84, 1250 - 1254. http://dx.doi.org/10.1016/j.sbspro.2013.06.738.

Costa, P. T., Terracciano, A., \& McCrae, R. R. (2001). Gender differences in personality traits across cultures: Robust and surprising findings. Journal of Personality and Social Psychology, 81(2), 322-331. http://dx.doi.org/10.1037/0022-3514.81.2.322

Crant, J. M. (1996). The proactive personality scale as a predictor of entrepreneurial intentions. Journal of Small Business Management, 34(3), 42-49. 
Cromie, S. (1987). Motivations of aspiring male and female entrepreneurs. Journal of Occupational Behaviour, 8(3), 251-261. http://dx.doi.org/10.1002/job.4030080306

De Miguel, A. (2005). Diferencias de edad y género en el NEO-PI-R en dos muestras con distinto nivel académico. International Journal of Psychology and Psychological Therapy, 1(1), 13-31.

De Noble, A. F., Jung, J., \& Ehrlich, S. B. (1999). Entrepreneurial self-efficacy: The development of a measure and its relationship to entrepreneurial action. In P. D. Reynolds, W. D. Bygrave, S. Manigart, C. M. Manson, G. D. Meyer, H. J. Sapienza, \& K. S. Shaver (Eds.), Frontiers of Entrepreneurship Research-1999 (pp 73-87). Wellesley, MA: Babson College.

Ehrhart, K. H. (2006). Job characteristic beliefs and personality as antecedents of subjective person-job fit. Journal of Business and Psychology, 21(2), 193-226. http://dx.doi.org/10.1007/s10869-006-9025-6

Hoffman, D. L., Novak, T. P., \& Schlosser, A. (2003). Consumer attitudes toward software filters and online content ratings: A policy analysis. Journal of Public Policy and Marketing, 22(1), 41-57. http://dx.doi.org/10.1509/jppm.22.1.41.17628

Jome, L. M., Donahue, M. P., \& Siegel, L. A. (2006). Working in the uncharted technology frontier: Characteristics of women web entrepreneurs. Journal of Business and Psychology, 21(1), 127-147. http://dx.doi.org/10.1007/s10869-005-9019-9

Justo, R., Cruz, C., De Castro, J., \& Coduras, A. (2005). Entrepreneur's perception of success: Is there really a gender divide? Paper presented at the RENT XIX Conference- Research in Entrepreneurship and Small Business, Napoles, Italia.

Krueger, N. F. (1993). The impact of prior entrepreneurial exposure on perceptions of new venture feasibility and desirability. Entrepreneurship Theory and Practice, 18(1), 5-21.

Krueger, N. F.(2000). The cognitive infrastructure of opportunity emergence. Entrepreneurship Theory and Practice, 24(3), 5-23.

Krueger, N., \& Brazeal, D. (1994). Entrepreneurial potential and potential entrepreneurs. Entrepreneurship Theory and Practice, 18(1), 91-104.

Krueger, N. F., \& Dickson, P. R. (1994). How believing in ourselves increases risk taking: Perceived self-efficacy and opportunity recognition. Decision Sciences, $25(3), \quad 385-400$. http://dx.doi.org/10.1111/j.1540-5915.1994.tb01849.x

Krueger, N. F., Reilly, M. D., \& Carsrud, A. L. (2000). Competing models of entrepreneurial intentions. Journal of Business Venturing, 15(5-6), 411-432. http://dx.doi.org/10.1016/S0883-9026(98)00033-0

Lüthje, C., \& Franke, N. (2003). The "making" of an entrepreneur: Testing a model of entrepreneurial intent among engineering students at MIT. $R \& D$ Management, 33(2), 135-147.http://dx.doi.org/10.1111/1467-9310.00288

McClelland, E., Swail, J., Bell, J., \& Ibbotson, P. (2005). Following the pathway of female entrepreneurs. A six country investigation. International Journal of Entrepreneurial Behaviour \& Research, 11(2), 84-107. http://dx.doi.org/10.1108/13552550510590527

Robinson, P. B., Stimpson, D. V., Huefner, J. C., \& Hunt, H. K. (1991). An attitude approach to the prediction of entrepreneurship. Entrepreneurship Theory and Practice, 9(4), 13-31.

Rohrmann, B. (1997). Risk Orientation Questionnaire: Attitudes towards risk decisions (pre-test version). Non-published manuscript, University of Melbourne, Melbourne, Australia.

Sánchez, J.C. (2011). University training for entrepreneurial competencies: Its impact on intention of venture creation. International Entrepreneurship Management Journal, 7 (239-254). http://dx.doi.org/10.1007/s11365-010-0156-x.

Sánchez, J.C. (2013). The Impact of an Entrepreneurship Education Program on Entrepreneurial Competencies and Intention. Journal of Small Business Management, 51(3), 447-465. http://dx.doi.org/10.1111/jsbm.12025.

Sánchez, J. C., Lanero, A., \& Yurrebaso, A. (2005). Variables determinantes de la intención emprendedora en el contexto universitario. Revista de Psicología Social Aplicada, 15(1), 37-60.

Sánchez, J.C., \& Licciardello, O. (2012). Gender differences and attitudes in entrepreneurial intentions: the role of career choice. Journal of Women's Entrepreneurship and Education, 1-2, 7-27. 
Segal, G., Borgia, D., \& Schoenfeld, J. (2005). The motivation to become an entrepreneur. International Journal of Entrepreneurial Behavior \& Research, 11(1), 42-57. http://dx.doi.org/10.1108/13552550510580834

Seibert, S. E., Kraimer, M. L., \& Crant, J. M. (2001). What do proactive people do? A longitudinal model linking proactive personality and career success. Personnel Psychology, 54(4), 854-874. http://dx.doi.org/10.1111/j.1744-6570.2001.tb00234.x

Shapero, A., \& Sokol, L. (1982). The social dimensions of entrepreneurship. In C. Kent, D. Sexton, \& K. H.Vesper (Eds.), Encyclopaedia of Entrepreneurship (pp.72-90). Englewood Cliffs, NJ: Prentice Hall.

Walters, L., McCabe, M., Kiellerup, D., \& Kiellerup, S. (2002). The role of formal mentoring on business success and self-esteem in participants of a new-business start-up program. Journal of Business and Psychology, 17(1), 107-121. http://dx.doi.org/10.1023/A:1016252301072

Wasylow, B., Mellot, R., \& Martin, W. E. Jr. (2006). The impact of vocational and personality factors on career development of first-year college students. In G. R. Walz, J. C. Bleuer, \& R. K. Yep (Eds), Vistas: Compelling perspectives on counselling 2006 (pp. 219-222). Alexandria, VA, US: American Counselling Association.

Wilson, F., Marlino, D., \& Kickul, J. (2004). Our entrepreneurial future: Examining the diverse attitudes and motivations of teens across gender and ethnic identity. Journal of Developmental Entrepreneurship, 9(3), 177-197.

Zhao, H., Seibert, S. E., \& Hills, G. E. (2005). The mediating role of self-efficacy in the development of entrepreneurial intentions. Journal of Applied Psychology, 90(6), 1265-1272. http://dx.doi.org/10.1037/0021-9010.90.6.1265 